\title{
Implementasi pariwisata berbasis masyarakat (CBT) di Coban Parang Tejo Malang
}

\author{
Siti Asiyah, Kartika Rose Rachmadi \\ Fakultas Ekonomi dan Bisnis, Universitas Islam Malang, Indonesia
}

This study uses a qualitative descriptive approach with a SWOT analysis tool; namely Internal-external situation analysis which aims to determine the strengths and weaknesses as well as the factors that become opportunities and threats for the development of the Coban Parang Tejo tourism area in Malang, and the application and implementation of Community Based Tourism principles for the development of the Coban Parang Tejo tourism area. The results of the study concluded that the concept of CBT has been applied in tourism management in Coban Parang Tejo (CPT) which was applied in the form of local community participation, the formation of a tourism village institution, environmentally friendly tourism management, the role of government, cooperation with investors and the creation of community business activities. From the SWOT analysis generated promotional strategies based on the strengths and weaknesses of tourism in CPT, 1) SO strategy by increasing the number of interesting vehicles adjusted to the local wisdom of the Perinci village community, so that it has its own distinct characteristics / uniqueness that is different from other tours; 2) ST Strategy by increasing the competitiveness of Coban Parang Tejo; 3) WO Strategy by increasing facilities / infrastructure and existing infrastructure; and 4) WT strategy by collaborating with investors and strengthening community communities. All of which are in the context of improving the welfare of the community.

OPEN ACCESS

ISSN 2528-4649 (online) ISSN 2338-4409 (print)

Reviewed by:

Asat Rizal \& Putu Anom Mahadwartha \& Nurul Qomariah

${ }^{*}$ Correspondence:

Received: 22 Juli 2020 Accepted: 25 Agustus 2020 Published: 30 September 2020

Citation:

Asiyah S and Rachmadi KR (2020) Implementasi pariwisata berbasis masyarakat (CBT) di Coban Parang

Tejo Malang. JBMP. 6:2.

doi: 10.21070/jbmp.v6i2.647
Keyword: Community Based Tourism (CBT); promotion strategies; and internal-

external situation analysis

Penelitian ini menggunakan pendekatan diskriptif kualitatif dengan alat analisis SWOT; yaitu analisis situasi Internal-eksternal yang bertujuan untuk mengetahui kekuatan dan kelemahan serta faktor-faktor yang menjadi peluang dan ancaman bagi pengembangan area wisata Coban Parang Tejo di Malang, serta penerapan dan implementasi prinsipprinsip Community Based Tourism guna pengembangan area wisata Coban Parang Tejo . Hasil penelitian menyimpulkan bahwa konsep CBT sudah diterapkan dalam pengelolaan pariwisata di Coban Parang Tejo (CPT) yang diaplikasikan dalam bentuk partisipasi masyarakat lokal, pembentukan kelembagaan desa wisata, pengelolaan wisata yang berwawasan lingkungan, adanya peran pemerintah, kerjasama dengan investor dan terciptanya kegiatan usaha masyarakat. Dari analisis SWOT dihasilkan strategi promosi yang berbasis kekuatan dan kelemahan wisata yang ada di CPT yaitu: 1) Strategi SO, yaitu dengan meningkatkan jumlah wahana yang menarik disesuaikan dengan kearifan local yang dimiliki masyarakat desa Perinci, sehingga mempunyai ciri khas/keunikan tersendiri 
yang berbeda dengan wisata lain; 2) Strategi ST, yaitu dengan meningkatkan daya saing Coban Parang Tejo; 3) Strategi WO, yaitu dengan peningkatan sarana / prasarana dan infrastruktur yang ada; dan 4) Strategi WT, yaitu dengan melakukan kerjasama dengan investor dan memperkuat paguyuban masyarakat. Yang semuanya dalam rangka meningkatkan kesejahteraan masyarakat

Kata kunci: Community Based Tourism (CBT); strategi promosi; dan analisis situasi internal-eksternal 


\section{PENDAHULUAN}

Dalam pendahuluan, Undang-Undang Republik Indonesia Nomor 10 Tahun 2009 tentang kepariwisataan menyebutkan bahwa pariwisata adalah berbagai macam kegiatan wisata dan didukung berbagai fasilitas serta layanan yang disediakan oleh masyarakat, pengusaha, pemerintah, dan pemerintah daerah. Pesatnya perkembangan pariwisata saat ini, merupakan bentuk nyata dari perjalanan bisnis global yang menjanjikan dalam meningkatkan sector pertumbuhan ekonomi yang dihasilkan dari pergerakan wisatawannya. Hal ini ditunjukkan oleh WTO (World Tourism Organization) bahwa pada tahun 1995 tercatat sebesar 565 juta wisatawan dalam pergerakan wisatawan dunia, dan membelanjakan uangnya total sebesar USD 401 milliar. Dan (Hermantoro, 2011:17) memperkirakan bahwa pada tahun 2020 akan terjadi pergerakan wisatawan sebanyak 1,6 miliar dengan total pembelanjaan sebesar USD 2.000 miliar atau dengan perkiraan pembelanjaan rata-rata sebesar lebih dari USD 5 miliar per hari.

Kegiatan pembangunan kepariwisataan juga merupakan proses pengembangan masyarakat, yang melibatkan proses penguatan masyarakat secara aktif dan berkelanjutan berdasarkan prinsip keadilan sosial, partisipasi dan kerjasama yang setara dengan mengekspresikan nilai-nilai keadilan, kesetaraan, akuntabilitas, kesempatan, pilihan, partisipasi, kerjasama, dan proses belajar yang berkelanjutan. Pada hakekatnya dalam pembangunan juga melibatkan peran dari seluruh pemangku kepentingan yang terkait. Dalam pariwisata, pihak yang berkepentingan meliputi 3 (tiga) pihak yaitu: Pemerintah, Swasta dan Masyarakat, yang mempunyai peran dan fungsi masing-masing (Murphy dalam Rahim (2012:2). Semua pihak yang berkepentingan tidak bisa berdiri sendiri, tetapi harus tetap bersinergi agar dapat mencapai tujuan dan sasaran pembangunan yang telah disepakati (Desa et al., 2015).

Dalam proses pemberdayaan wisata berbasis masyarakat (BCT) pada Coban Parang Tejo sebagai tujuan wisata yang unik di Malang membutuhkan pemahaman-pemahaman yang lebih mendalam terhadap karakteristik wilayah Perinci Dau dan sekitarnya. Untuk mengembangkan kawasan Coban Parang Tejo dibutuhkan keterlibatan semua pihak baik pemerintah terkait, masyarakat, usaha pariwisata maupun LSM yang ada. Bagaimana konsep, pengembangkan strategi promosi, menginventarisir kendala-kendala Wisata Berbasis Masyarakat diterapkan.

Potensi alam dan juga kearifan lokal yang dimiliki oleh Kabupaten Malang merupakan modal besar yang dapat di implikasikan untuk meningkatkan kesejahteraan masyarakat. Kabupaten Malang merupakan salah satu daerah yang berada di Malang raya, hasil pemekaran dari Kabupaten Malang bagian utara, kota ini memiliki panorama yang cantik, indah dengan cuaca yang dingin serta sejuk tidak terkecuali untuk pariwisata yang beragam dan cukup mempunyai "nama" dikalangan turis lokal maupun internasional. Salah satu dari sekian banyak pariwisata di Kabupaten Malang yaitu Air Terjun Parang Tejo atau bisa dikenal juga dengan Coban Parang
Tejo yang berada di daerah Perinci Dau. Objek wisata ini memanjakan keindahan, kondisi air yang jernih dan juga beberapa spot foto. Coban Parang Tejo termasuk salah satu objek wisata yang masih baru. Hal ini dikarenakan belum banyak wisatawan yang datang ke tempat ini. Sehingga masih membutuhkan pemasaran berupa promosi dan juga pembenahan bahkan penambahan wahana-wahana yang menarik di beberapa titik lokasi.

CPT sebagai salah satu destinasi wisata ini akan menjadi daya tarik tersendiri bagi wisatawan yang akan berkunjung ke Malang, selain ke Coban Rais, Coban Talun, maka akan ada CPT yang nantinya akan menjadi alternative bagi wisatawan yang ingin berkunjung ke Malang. Dari hasil penelitian di atas, diketahui bahwa permasalahan yang ada dalam penelitian ini adalah: Bagaimana konsep Wisata Berbasis Masyarakat diterapkan dalam upaya mengembangkan Coban Parang Tejo sebagai destinasi wisata di Malang dan Bagaimana mengembangkan strategi promosi yang tepat guna mendukung kegiatan pengembangan Coban Parang Tejo sebagai destinasi wisata.

Adapun tujuan dari penelitian ini adalah untuk mengidentifikasi faktor internal dan eksternal pada CPT; merumuskan strategi promosi yang tepat; dan mengidentifikasi kendalakendala yang ada di CPT.

\section{METODE (UNTUK ARTIKEL HASIL PENELITIAN)}

Jenis penelitian yang digunakan penulis dalam penelitian ini adalah kualitatif deskriptif. Menurut Sugiyono (2010), penelitian kualitatif deskriptif adalah "penelitian yang berlandaskan pada filsafat postpositivisme, digunakan untuk meneliti pada kondisi obyek yang alamiah, (sebagai lawannya adalah eksperimen) dimana peneliti adalah sebagai instrument kunci, pengambilan sampel sumber data dilakukan secara prposive, teknik pengumpulan dengan trianggulasi (gabungan), analisis data bersifat induktif/kualitatif, dan hasil penelitian kualitatif lebih menekankan makna dari generalisasi". Teknik penelitian ini adalah teknik purposive sampling. Data yang digunakan dalam penelitian ini adalah data primer melalui wawancara beberapa narasumber baik dari Parangtejo maupun pihak investor dan data sekunder diperoleh dari data pengunjung dan data lain terkait parwisata tersebut.

Metode analisis data yang digunakan dalam penelitian yaitu analisis situasi internal-eksternal: mengidentifikasi situasi internal berupa faktor-faktor yang menjadi kekuatan dan kelemahan dan faktor-faktor yang menjadi peluang dan ancaman bagi pengembangan CPT sebagai daerah tujuan wisata di Kabupaten Malang. Identifikasi situasi ini merupakan basis informasi untuk analisis matriks SWOT, dengan tahapan: 1) Buat daftar kekuatan internal, 2) Buat daftar kelemahan internal, 3) Buat daftar peluang eksternal, dan 4) Buat daftar ancaman eksternal sentra pengembangan $\mathrm{CPT}$ sebagai daerah tujuan wisata di Dau - Malang. 


\section{HASIL DAN PEMBAHASAN}

Berdasarkan hasil wawancara dengan beberapa informan/pihakpihak yang berkepentingan terkait pengelolaan dan pengembangan CPT sebagai destinasi di desa Perinci Dau Malang, maka dapat disimpulkan bahwa masyarakat desa Perinci pada prinsipnya sudah menerapkan konsep CBT dalam pengelolaan CPT sebagai destinasi wisata di Malang. Hal ini bisa ditunjukkan dengan adanya inisiatif dari masyarakat yang dikomandani oleh p. Riswaji sebagai ketua LKDPH (Lembaga Kelestarian Daerah Pengembang Hutan) desa Perinci dengan mengajak masyarakat setempat untuk bersama-sama memikirkan dan melakukan upaya-upaya dalam mengelola CPT. Keberadaan CPT bisa memberikan manfaat lebih kepada masyarakat dengan membersihkan jalan-jalan yang menuju lokasi wisata, merawat, mengelola hutan, dan menanam bunga-bunga disekitar hutan yang intinya masyarakat setempat welcome dengan ajakan P. Riswaji untuk mengelola CPT. P.Riswaji dengan dukungan P. Bentung dari Perhutani bersama masyarakat bahu membahu mengelola CPT. Akan tetapi mengelola tempat wisata tanpa ilmu pariwisata akan sulit mendapatkan hasil yang sesuai dengan yang diharapkan. Akhirnya demi mendapatkan hasil dan kemanfaatan yang maksimal untuk masyarakat, maka mereka sepakat untuk menggandeng investor guna pengembangan wisata CPT ke depan dan menjadikan CPT sebagai salah satu tujuan wisata di daerah Malang. PT. Riski merupakan investor yang disepakati dalam mengembangkan CPT.

Realita di atas merupakan bukti bahwa dalam pengelolan wisata CPT sudah menggunakan konsep CBT. Hanya saja karena rendahnya pendidikan masyarakat, minimnya pengalaman masyarakat dalam mengelola pariwisata serta tidak adanya latar belakang pekerjaan yang terkait dengan bidang wisata, maka masyarakat kesulitan dalam mengelola dan mengembangkan wisata CPT sebagai destinasi wisata. Untuk lebih jelasnya maka dibawah ini akan peneliti tunjukkan analisis diskriptif terkait penerapan konsep wisata berbasis CBT yang harus memiliki unsur-unsur seperti adanya keterlibatan/partisipasi masyarakat setempat, adanya kelembagaan yang mendukung, ada investor dan ada peran pemerintah sebagai fasilitator.

\section{- Partisipasi Masyarakat Lokal}

Partisipasi masyarakat yang ada di desa Perinci dalam rangka pengelolaan CPT sebagai destinasi wisata sudah menunjukkan adanya peran dan keterlibatan masyarakat setempat dalam mengelola sebuah wisata sebagai destinasi wisata di daerah mereka. Realita ini menunjukkan bahwa masyarakat sudah menerapkan konsep CBT, seperti yang dikatakan oleh (Intyaswono, Yulianto and Mawardi, 2016) bahwa ada tiga prinsip pokok dalam strategi perencanaan pembangunan pariwisata yang berbasis CBT yang salah satunya adalah adanya keterlibatan masyarakat dalam pengambilan keputusan. Hal ini dibuktikan pada tahap pengambilan keputusan untuk memilih investor, maka masyarakat desa Perinci yang disini diwakili oleh P. Riswaji juga ikut berperan dan terlibat dalam menentukan investor mana yang akan dipilih dan diberi hak untuk mengelola dan mengembangkan CPT sebagai destinasi wisata.

Hal ini senada dengan pendapat dari (Tomas L.P. et al. 2011), bahwa penerapan partisipasi aktif dari masyarakat lokal yang berdasarkan prinsip Community Based Tourism (CBT) meliputi partisipasi dari tahap perencanaan hingga pengambilan keputusan dalam pengelolaan wisata. Lebih jauh (Asker Sally et al.2010) mengemukakan bahwa CBT yang efektif memerlukan partisipasi aktif dari komunitas lokal mulai dari perencanaan, penilaian hingga implementasi. Hanya saja sesuai dengan yang dikemukakan oleh (Rachmawati;2014), bahwa karena rendahnya pendidikan masyarakat lokal, maka masyarakat lokal masih belum memiliki kemampuan untuk berperan aktif dalam pengelolaan wisata. Meskipun masyarakat memiliki tingkat pengetahuan dan persepsi yang baik terkait kawasan, tetapi masyarakat masih belum mengenal dan memahami industri wisata dan bagaimana mengelola wisata. Hal inilah yang menjadi penghambat keberlangsungan partisipasi masyarakat dalam mengembangkan CPT sebagai destinasi wisata.

\section{- Pembentukan Kelembagaan Desa}

Terkait dengan salah satu pinsip dari konsep CBT yang menjelaskan bahwa harus ada lembaga yang terbentuk di masyarakat sebagai wadah dalam menampung aspirasi masyarakat. Kelembagaan wisata di desa Perinci sebenarnya sudah ada, bahkan lembaga kerjasama desa dengan LKDPH (Lembaga Kelestarian Daerah Pengembangan Hutan) tersebut sudah terbagi dalam tugas dan bagian masing-masing. Hal ini membuktikan bahwa lembaga wisata di desa Perinci sudah berjalan dengan baik. Akan tetapi di lapangan, peran lembaga tersebut kurang berjalan dengan baik dikarenakan tidak semua pengurus memiliki kesadaran dan pengetahuan yang baik tentang kepariwisataan. Sehingga sering terjadi perselisihan dan ketidak samaan pandangan diantara pengurus, yang menyebabkan kinerja lembaga kurang optimal. Tidak jarang pengurus bertindak sendiri-sendiri, pengurus mempunyai konsep pengelolaan yang berbeda sehingga mereka membuat keputusan yang berbeda pula. Hal ini mengakibatkan hubungan yang kurang baik dan harmonis, diantara pengurus. Untuk mengatasi hal ini, diperlukan komunikasi dan koordinasi yang lebih baik serta kesadaran ingin mengembangkan wisata CPT secara bersama-sama, agar pengelolaan dan pengembangan wisata berjalan ke arah yang lebih maju.

\section{- Kerjasama yang kuat dengan stakeholder terkait konsep CBT}

Dari hasil wawancara juga diketahui bahwa masyarakat Perinci dengan pihak Perhutani sudah melakukan kerjasama dengan pihak stakeholder, dalam hal ini pihak CV. Rizky merupakan stakeholder yang dipercaya dalam mengelola dan mengembangkan CPT. Adanya kelompok masyarakat yang telah mengadakan kerjasama dengan pihak investor guna mengelola wisata, hal ini membuktikan bahwa masyarakat tersebut telah menerapkan konsep CBT dalam mengelola CPT sebagai desti- 
nasi wisata. Kerjasama masyarakat dengan stakeholder merupakan salah satu kunci keberhasilan dalam mengembangkan sebuah konsep CBT.

- Peran Pemerintah sebagai fasilitator (Perhutani)

Dalam mengembangkan CPT sebagai destinasi wisata di Malang, sebenarnya pemerintah mempunyai peran strategis sebagai fasilitator. Bahkan dalam kasus CPT ini, pemerintah yang mempunyai hak karena lokasi CPT masuk area perhutani, sehingga dalam pengelolaannya masyarakat harus mendapat ijin dari Perhutani. Perhutani bersama masyarakat sudah bekerjasama dalam mengembangkan Coban Parang Tejo sebagai Kawasan wisata, dimana kerjasamanya tersebut menghasilkan kesepakatan untuk mengggandeng investor (CV. Rizky) dalam mengembangkan CPT menjadi destinasi wisata yang bisa bersaing dengan wisata yang lain. Dan peran pemerintah sebagai fasilitator sudah dijalankan, meski dalam realitanya masih perlu ditingkatkan guna meningkatkan hubungan baik dengan masyarakat setempat.

\section{Merumuskan Strategi Promosi Yang Tepat guna meningkatkan pengelolaan destinasi wisata CPT}

Untuk merumuskan strategi promosi yang tepat, maka perlu dianalisis dengan analisis SWOT yang meliputi faktor kelebihan, kelemahan, peluang dan ancaman pada wisata CPT. Dibawah ini akan diidentifikasi faktor-faktornya lihat tabel (5.1). Berdasarkan kombinasi faktor-faktor kelebihan, kelemahan, peluang dan ancaman, maka metode interpretasinya dapat dirumuskan sebagai strategi SO, ST, WO dan WT.

\section{Strategi SO, menciptakan strategi dengan menggunakan kekuatan untuk memanfaatkan peluang, yaitu:}

Meningkatkan jumlah wahana wisata yang menarik, hal ini perlu dilakukan karena di CPT merupakan area wisata yang masih alami, sejuk dan indah pemandangannya, sehingga perlu sentuhan-sentuhan kreatifitas dari pengelola dalam membuat wahana/spot wisata yang bagus dan menarik agar CPT bisa menarik wisatawan baik local maupun mancanegara. Dengan pengelolaan yang professional dalam membuat spotspot wisata, maka CPT akan mempunyai daya tarik tersendiri bagi pengunjung. Strategi SO dapat dirumuskan beberapa program, antara lain:

- Membuat spot wahana wisata yang sesuai dengan masyarakat milenial; hal ini dikarenakan, spot wahana wisata yang ada di CPT masih terlihat sederhana dan kurang begitu menarik dibanding spot foto yang ada di wisata pesaing seperti Coban Rais, Coban Putri maupun Batu Flower Garden sehingga masyarakat millennial kurang terpuaskan bila mereka akan melakukan foto selfi. Oleh karena itu di CPT perlu dibuatkan spot-spot foto yang menarik, modern dan sesuai selera mile- nial agar bisa menarik minat pengunjung.

- Membuat area camping yang disesuaikan dengan kebutuhan pengunjung; terkait area camping ini, sebenarnya CPT memiliki kelebihan dibanding area camping yang ada di tempat wisata yang lain (Misal Bedengan - Selorejo) hal ini dikarenakan area camping di CPT masih asli dan asri, memiliki lahan yang luas dan dari segi harga masih murah. Akan tetapi area camping di CPT ini termasuk area camping yang masih sedikit peminatnya, karena masih belum dilengkapi oleh sarana dan prasarana yang dibutuhkan oleh orang camping. Untuk itu di area camping perlu dibangun sarana dan prasarana yang mendukung daya tarik dari area ini seperti dibangunnya fasilitas toilet umum, spotspot foto instragramble, warung yang menjual kebutuhan untuk camping mulai makanan sampai peralatan mandi, maupun tempat penyewaan peralatan camping, sehingga akan semakin menarik minat orang untuk camping.

- Membuat area wisata jeruk/sayuran; untuk meningkatkan jumlah wisata yang berkunjung di wisata CPT, maka perlu dibuat paket wisata yang menghubungkan dengan wisata lain yang ada di sekitar lokasi seperti wisata petik jeruk di Desa Selorejo. Pengunjung sebelum masuk CPT perlu diajak keliling dari CPT sampai wisata petik jeruk Selorejo yang lokasinya berdekatan dengan wisata petik atau makan buah jeruk langsung dari pohonnya. Dengan konsep ini diharapkan pengunjung memiliki sensasi berbeda ketika berkunjung ke wisata CPT, yang sifatnya unik. Demikian juga dengan sayuran, sayuran yang dihasilkan petani desa Perinci bisa dijadikan daya tarik wisata dengan konsep wisata petik sayuran sendiri langsung dari lahannya.

\section{Strategi WO, menciptakan strategi dengan meminimalkan kelemahan dan memanfaatkan peluang, yaitu:}

Meningkatkan sarana/prasarana dan infrastruktur, seperti fasilitas pengunjung dan jalan yang ada di CPT sangat perlu dan mendesak untuk dilakukan perbaikan dan pembangunan jalan-jalan sebagai akses masuk wisata CPT. Hal ini dikarenakan akses jalan masuk wisata CPT masih jelek dan sempit, sehingga pengunjung yang hendak berkunjung agak kesulitan atau terhambat. Juga lokasinya yang sulit menyebabkan pengunjung yang tidak memiliki kendaraan sulit untuk mencapai tempat ini, untuk itu akses jalan ke jalan raya perlu dibangun biar semakin meningkatkan jumlah pengunjung. Dengan semakin mudahnya CPT dijangkau maka akan semakin meningkatkan minat masyarakat untuk berkunjung. Adapun program yang perlu dilakukan adalah:

- Perbaikan jalan/akses; disamping membangun dan memperbaiki akses jalan, maka di area CPT ini perlu dibangun jalur khusus untuk menuju area camping. Dimana untuk pengunjung yang ingin camping biasanya lebih senang kalau naik motor tril atau jeep. Hal ini akan menambah daya tarik 
tersendiri bagi orang yang mau camping.

- Pengembangan fasilitas pengunjung; terkait dengan perlunya pengembangan fasilitas pengunjung, hal ini dikarenakan di area wisata CPT masih belum ada fasilitas umum seperti toilet umum dan mushollah untuk kepentingan dan kenyamanan pengunjung. Untuk warung atau restoran sudah ada, hanya saja kontinuitas bukanya yang masih perlu ditingkatkan. Karena warung hanya buka ketika hari minggu atau hari-hari libur saja. Sehingga ini membuat pengunjung CPT kesulitan kalau mau mencari makanan dan minuman disaat mereka merasa haus dan lapar setelah keliling melihat view-view yang ada di area wisata.

- Peningkatan fungsi pada Bumdes, dengan memanfaatkan dana Bumdes untuk pengembangan wisata CPT yang bersifat pemberian modal, maka Bumdes akan mendapatkan pendapatan dari dana yang dipergunakan untuk pembiayaan pengembangan CPT tersebut. Yang pada akhirnya CPT dapat menjadi daerah wisata yang menarik dan Bumdes juga berkembang secara komersil.

\section{Strategi ST, menciptakan strategi dengan menggunakan kekuatan untuk mengatasi ancaman, yaitu:}

Meningkatkan daya saing CPT sebagai area wisata yang berdasar komunitas. CPT merupakan asset yang berharga bagi desa Perinci, untuk itu potensi yang ada di CPT harus dikembangkan secara berkelanjutan. Yaitu dengan pemanfaatan sumber daya yang ada di dalamnya, mulai dari air terjun, hutan, pemandangan yang asri dan lingkungan yang bersih untuk ditingkatkan pemanfaatannya menjadi daya tarik bagi pengunjung yang datang ke CPT.

Adapun program yang diantaranya yaitu:

- Memasukkan kearifan lokal; maksudnya dengan memberdayakan masyarakat setempat yang mempunyai keahlian seni baik seni lukis, tari maupun tarik suara untuk diikut sertakan dalam program pengembangan wisata $\mathrm{CPT}$ yang berbasis kearifan local. Maka wisata di CPT akan mempunyai keunikan tersendiri yang berbeda dengan wisata lain yang sejenis, dikarenakan tiap desa mempunyai budaya/seni yang berbeda dengan desa lain. Hal inilah yang dapat digunakan sebagai alat untuk meningkatkan daya saing dari wisata CPT.

- Membuat wahana unik yang berbeda dengan pesaing; hal ini diperlukan karena wahana/spot foto yang ada di CPT tergolong masih sederhana dan tidak modern serta kalah kalau dibandingkan dengan spot foto yang ada di wisata pesaing. Sehingga pembuatan wahana/spot foto yang menarik dengan design yang menunjukkan identitas wisata CPT, tentunya akan meningkatkan daya tarik CPT.

c. Peningkatan promosi; hal ini sangat urgen dilakukan karena sekarang semua promosi harus dilakukan lewat media social mulai Facebook, WA maupun Instragram. Untuk itu pihak pengelola wisata CPT harus melakukan promosi lebih gencar lagi, kalaupun sudah melakukan promosi lewat medsos, maka promosi harus ditingkatkan lagi baik kuantitas maupun kualitasnya. Selain itu untuk memperkenalkan wisata CPT, pihak pengelola perlu memanfaatkan even-even pariwisata yang telah dirancang oleh pemerintah Kabupaten Malang sebagai sarana promosi dan pengenalan obyek wisataCPT kepada pengunjung local maupun luar negeri.

2. Meningkatkan pemeliharaan dan pengawasan hutan guna menjaga kelestarian hutan dan menjaga hutan terhadap orang-orang yang tidak bertanggung jawab. Adapun program yang dilakukan adalah:

a. Melakukan penghijauan/reboisasi; hal ini dilakukan agar hutan tetap terjaga kelestariannya. Mengoptimalkan potensi hutan dan keunikan alam dengan mempertahankan dan pemeliharaan hutan secara berkesinambungan untuk menghadapai persaingan antar obyek wisata.

b. Melakukan sosialisasi kepada masyarakat arti pentingnya hutan; hal ini dilakukan guna meningkatkan pengetahuan masyarakat akan pentingnya hutan, serta adanya rasa memiliki terhadap hutan yang ada di sekitar masyarakat. Dan menindak tegas terhadap masyarakat yang dengan sengaja melakukan pengrusakan hutan.

- Memperbaiki hubungan dengan masyarakat sekitar; selain menjaga dan melestarikan hutan, maka pemerintah desa juga perlu menjalin komunikasi dengan masyarakat agar hubungan dengan masyarakat terjalin dengan baik dan harmonis.

\section{Strategi WT, menciptakan strategi yang meminimalkan kelemahan dengan menghindari ancaman, yaitu:}

Pada strategi ini, pihak pengelola CPT perlu melakukan pendekatan secara persuasive terhadap kelompok masyarakat yang ada guna mengetahui keinginan dan harapan masyarakat terhadap pengelola.

- Melakukan kerjasama dengan investor; hal ini diperlukan sebagai penanam modal untuk meningkatkan pengelolan area wisata CPT agar menjadi wisata yang memiliki daya saing dibanding dengan wisata pesaing. Karena dengan hadirnya investor, CPT diharapkan akan berkembang dan memberi kemanfaatan yang besar bagi masyarakat khususnya masyarakat desa Perinci.

- Memperkuat paguyuban masyarakat; untuk meningkatkan peran masyarakat dalam pembangunan khususnya peran dalam mengembangkan wisata yang ada di CPT, maka pemerintah desa perlu melibatkan dan meningkatkan hubungan dengan masyarakat yaitu dengan menjalin komunikasi dan memperkuat paguyuban masyarakat yang ada di kelompok-kelompok mereka, agar terjalin hubungan yang harmonis. Sehingga akan meningkatkan rasa memiliki terhadap wisata CPT dari kelompok masyarakat tersebut.

[Table 1 about here.] 


\section{Identifikasi kendala-kendala yang ada} sebagai pertimbangan dan bahan evaluasi bagi pengembangan CPT sebagai destinasi wisata di Malang:

a. Rendahnya pendidikan masyarakat setempat, mengakibatkan penerapan konsep CBT (Community Based Tourism) mengalami hambatan;

b. Kurangnya komunikasi antar elemen masyarakat yang ikut berkontribusi dalam pengembangan CPT, sehingga tiap elemen bekerja sendiri-sendiri sehingga hasilnya kurang optimal;

c. Rendahnya komitmen antar elemen masyarakat dalam mengembangkan konsep CBT;

d. Kurangnya dukungan dari pemkab maupun dinas pariwisata;

e. Kurangnya modal;

f. Masih belum dikelola dengan profesional;

g. Investor yang ada kurang memahami karakter dan budaya masyarakat setempat, sehingga mengalami hambatan dalam menjalankan peran dan fungsinya.

\section{KESIMPULAN}

Kesimpulan dalam penelitian ini adalah: Penerapan konsep Based Community Tourism (CBT): Desa wisata Perinci yang memiliki Coban Parang Tejo sebagai destinasi wisata merupakan desa berpotensi yang masyarakatnya memiliki kepedulian tinggi dalam mengelola dan mengembangkan wisata yang ada di dalamnya. Konsep CBT sudah diterapkan dalam pengelolaan pariwisata yang diaplikasikan dalam bentuk partisipasi masyarakat lokal, pembentukan kelembagaan desa wisata, pengelolaan wisata yang berwawasan lingkungan, adanya peran pemerintah, kerjasama dengan investor dan terciptanya kegiatan usaha masyarakat. Dari hasil analisis SWOT dapat dirumuskan bahwa strategi promosi yang tepat dalam mengembangkan CPT adalah 1) Strategi SO, yaitu dengan meningkatkan jumlah wahana yang menarik disesuaikan dengan kearifan local yang dimiliki masyarakat desa Perinci, sehingga mempunyai ciri khas/keunikan tersendiri yang berbeda dengan wisata lain; 2) Strategi ST, yaitu dengan meningkatkan daya saing Coban Parang Tejo; 3) Strategi WO, yaitu dengan peningkatan sarana / prasarana dan infrastruktur yang ada; dan 4) Strategi WT, yaitu dengan melakukan kerjasama dengan investor dan memperkuat paguyuban masyarakat. Yang semuanya dalam rangka meningkatkan kesejahteraan masyarakat. Terkait berbagai kendala yang menghambat penerapan CBT (Based Community Tourism), maka para pengelola CPT harus bersinergi, dan bekerjasama dengan seluruh elemen yang ada, baik masyarakat, LKDPH, kepala desa, pihak perhutaani, investor maupun pihak Pemkab.

Saran dalam penelitian :

Perlunya pendampingan dan bimbingan kepada masyarakat desa Perinci, guna peningkatan pemahaman masyarakat tentang peran dan tanggung jawab mereka dalam berpartisipasi aktif pada pengelolaan wisata CPT. Perlunya kejelasan tugas masing-masing pengurus dalam mengembangkan CPT. Kerjasama dengan pihak-pihak yang terlibat dalam pengembangan CPT perlu dibentuk kesepakatan tertulis untuk menghindari konflik dikemudian hari. Perlu adanya konsep perencanaan pengembangan CPT secara tertulis dan disepakati bersama antar pengurus agar target yang dicapai jelas. Perlunya dukungan dari pemerintah terkait peraturan, kebijakan dan regulasi yang mengatur mekanisme pengembangan dan pengelolaan wisata. Untuk menjaga kelestarian hutan, perlu pembuatan kode etik atau peraturan tertulis terhadap fungsi hutan yang digunakan dalam kegiatan pariwisata.

\section{UCAPAN TERIMA KASIH}

Pada kesempatan ini saya ucapkan banyak terima kasih kepada LPPM Unisma yang telah mendanai penelitian ini, juga naras umber seperti p. Riswaji, P. Bentung, P. Wahyu Edy selaku Kades desa Gading dan P. Udin selaku investor di CPT, yang banyak membantu atas terselesaikannya penelitian ini.

\section{REFERENSI}

Asker S.et., al. (2010). Effective Community Based Tourism: a Best Practice Manual. Sustainable Tourism Cooperative Research Center

Binahayati, Rusyidi dan Muhammad, Fedryansah. (2018). Pengembangan Pariwisata Berbasis Masyarakat. Jurnal Pekerjaan Sosial. ISSN: 2620-3367 Vol. 1 No: 3 Hal: 155 - 165

CIFOR. 2004. Pembangunan Pariwisata Berbasis Masyarakat

Delita, dkk. 2011. Analisis SWOT Untuk Strategi Pengembangan Obyek Wisata Pemandian Mual Mata Kecamatan Pematang Bandar Kabupaten Simalungun

Desa, D. et al. (2015) 'PENELITIAN TERAPAN Tahun 2015, (April).

Devy, H. A. (2017). Pengembangan Obyek Dan Daya Tarik Wisata Alam Sebagai Daerah Tujuan Wisata Di Kabupaten Karanganyar,' Jurnal Sosiologi DILEMA, 32(1), pp. 34-44.

Intyaswono, S., Yulianto, E. and Mawardi, M. (2016) 'PERAN STRATEGI CITY BRANDING KOTA BATU DALAM TREND PENINGKATAN KUNJUNGAN WISATAWAN MANCANEGARA (Studi Pada Dinas Pariwisata dan Kebudayaan Kota Batu)', Jurnal Administrasi Bisnis S1 Universitas Brawijaya, 30(1), pp. 65-73.

Permana, C. H. A. and Purnomo, D. (2016). Evaluasi Program Pemberdayaan Masyarakat (Suatu Analisis Dalam Perspektif Pemberdayaan Masyarakat)', Cakrawala Jurnal Penelitian Sosial, 3(1), pp. 1-19.

Primadany, S. (2013) 'Analisis Strategi Pengembangan Pariwisata Daerah (Studi Pada Dinas Kebudayaan Dan Pari- 
wisata Daerah Kabupaten Nganjuk), Jurnal Administrasi Publik Mahasiswa Universitas Brawijaya, 1(4), pp. 135-143.

Susilo, A. (2016) 'Model Pemberdayaan Masyarakat Perspektif Islam, FALAH: Jurnal Ekonomi Syariah, 1(2), pp. 193209. doi: 10.22219 /jes.v1i2.3681.

Eva, Rachmawati. (2014). Mampukah Masyarakat Lokal, Menjadi Pengelola Wisata? Risalah Kebijakan Pertanian dan Lingkungan. Vol 1. No. 1

Hermawan, Heri. (2008). Analisis Pengembangan Kebijakan Pariwisata Indonesia (Studi Perbandingan Kebijakan Pariwisata Indonesia dengan Malaysia). Jurnal Kepariwisataan Indonesia, 3 (1): 13-35

Hermantoro, Hengky. (2011). Creative-Based Tourism Dari Wisata Kreatif Menuju Wisata Kreatif. Yogyakarta: Galangpress.

Husein, Umar. (2003). Metode Riset Perilaku Konsumen Jasa. Yogyakarta: Ghalia I

Rachmawati, E., Sunkar, A. 2012. Pengembangan Ekowisata Gua Di Jawa Barat. Laporan Penelitian Unggulan Perguruan Tinggi (Desentralisasi). Lembaga Penelitian dan Pengabdian Kepada Massyarakt. Institut Pertanian Bpgor.

Rizkianto dan Topowijono. (2018). Penerapan Konsep Community Based Tourism Dalam Pengelolaan Daya Tarik Wisata Berkelanjutan (Studi Pada Desa Wisata Bangun, Kecamatan

Munjungan, Kabupaten Trenggalek). Jurnal Administrasi Bisnis. Vol. 58 No.2.

Rangkuti. (2003). Analisis SWOT Teknik Membedah Kasus Bisnis. Jakarta: Gramedia Pusaka Utama.

Conflict of Interest Statement: The authors declare that the research was conducted in the absence of any commercial or financial relationships that could be construed as a potential conflict of interest.

Copyright (๑) 2020 Asiyah and Rachmadi. This is an open-access article distributed
Ryalita, Sefira. (2009). Analisis Strategi Pengembangan Pariwisata Daerah (Studi pada Dinas Kebudayaan dan Pariwisata Daerah Kabupaten Nganjuk)

Sugiyono. 2013. Metode penelitian kuantitatif, kualitatif dan R\&D. Bandung: Alfabeta.

Sugi, Rahayu, dkk. (2015). Pengembangan Pariwisata Berbasis Masyarakat (COMMUNITY BASED TOURISM) Di Kabupaten Kulon Progo Daerah Istimewa Yogyakarta. Laporan Penelitian Hibah Bersaing.

Suharto, Edi (2009), Pekerjaan Sosial di Dunia Industri: Memperkuat Tanggungjawab Sosial Perusahaan (Corporate Social Responsibility), Bandung: Refika Aditama

Sunaryo, Bambang. (2013). Kebijakan Pembangunan Destinasi Pariwisata Konsep dan Aplikasinya di Indonesia. Yogyakarta: Gava Media

Sujarwo dan Lutfi, Wibawa. 2013. Analisis Permasalahan Perempuan dan Potensi Lokal. laporan penelitian Yogyakarta; Fakultas Ilmu Pendidikan UNY (laporan penelitian tidak dipublikasikan)

Tomas et.sl. (2011). Community-Based Tourism in Developing Countrie: A Case Study. Tourismos: An International Multiciplinary Journal of Tourism Vol 6 No 1 Spring 2011 pp: 69-84. World Tourism Organization Agenda

Undang-undang Nomor 10 Tahun 2009 Tentang Kepariwisataan. 2008. Surabaya: Diperbanyak oleh CV Pustaka Agung Harapan Surabaya

Yoeti, O. (1996). Pengantar Ilmu Pariwisata. Penerbit Angkasa. Bandung.

Sugiyono. (2013). Metode penelitian kuantitatif, kualitatif dan R\&D. Bandung: Alfabeta.

under the terms of the Creative Commons Attribution License (CC BY). The use, distribution or reproduction in other forums is permitted, provided the original author(s) and the copyright owner(s) are credited and that the original publication in this journal is cited, in accordance with accepted academic practice. No use, distribution or reproduction is permitted which does not comply with these terms. 


\section{LIST OF TABLES}

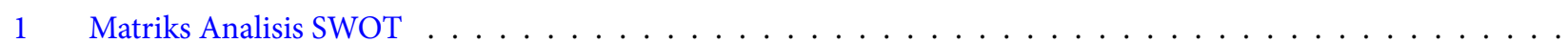


TABLE 1 | Matriks Analisis SWOT

INTERNAL/EKSTERNAL

Peluang (Opportunity)

1.Tingginya minat masyarakat untuk camping

2.Dekat dengan wisata petik jeruk Selorejo

3.Perkembangan pariwisata cukup pesat

4.Kebijakan pemerintah terkait pengembangan desa

berbasis kearifan lokal

5.Penghasil sayuran dan buah berupa jeruk

Ancaman (Threat)

1. Banyaknya pesaing

Rusaknya hutan
Kekuatan (Strength)

1. Pemandangan alam yang asri

2. Terdapat hutan pinus

3. View yang menarik

4. Lokasi dekat dengan Malang

5. Ada area camping

6. Parkir luas

Ada air terjun

Strategi SO

Strategi : meningkatkan jumlah wahana wisata yang menarik

Program :

1. Membuat spot wahana wisata yang sesuai dengan masyarakat milenial

2. Membuat area camping yang disesuaikan dengan kebutuhan pengunjung

3. Membuat area wisata jeruk/sayuran

Membuat paket wisata misalna dari CPT sampai wisata petik jeruk selorejo

Strategi ST

Strategi : meningkatkan daya saing CPT

Program :

1. Memasukkan kearifan lokal

2. Membuat wahana unik yang berbeda dengan

pesaing

3. Peningkatan promosi

Strategi : meningkatkan penjagaan hutan

Program :

4. Melakukan penghi-jauan/reboisasi

5. Melakukan sosialisasi kepada masyarakat arti

pentingnya hutan

6. Memperbaiki hubungan dengan masyarakat sekitar
Kelemahan (Weaknes)

1. Akses kurang baik

2. Kurangnya modal

3. Wahana yang tersedia kurang sesuai

4. Wahana yang ada kurang dirawat

Fasilitas pengunjung kurang memadai

Strategi WO

Strategi : peningkatan sarana/prasarana dan infrastuktur yang ada

Program :

1. Perbaikan jalan/akses

2. Pengembangan fasilitas pengunjung

Peningkatan fungsi pada bumdes

Strategi WT

1.Melakukan kerjasama dengan investor

2.Memperkuat paguyuban masyarakat

Sumber: (Hasil olah data, 2020) 